\title{
Technology to boost agricultural efficiency
}

\author{
ERKKI H. OKSANEN \\ Work Efficiency Institute, Helsinki, Finland \\ Box 28, 00211 Helsinki
}

The proportion of agricultural and forestry workers in the total labour force has been drastically reduced from $46 \%$ in 1950 to 20 $\%$ in 1970 , the latter figure having been halved to slightly less than $10 \%$ towards the end of the 1980's (Indicators of the Finnish Economy 1989). Agricultural production has, however, grown to such an extent that restrictions have had to be introduced. This implies that work efficiency or the (net) output of agricultural production per working hour (SUOMELA 1958) has rapidly increased, exceeding the growth in many other fields of endeavour. The growth would not have been possible without mechanization and other rationalization measures,

Studies in various countries have suggested that production growth is attributable roughly in equal measure to mechanization on the one hand, and to breeding of plants and domestic animals, the use of fertilizers and more efficient weed, pest and disease control on the other hand.

On the farms participating in the agricultural profitability study the utilization of human labour at the beginning of the 1960's in day-to-day agricultural tasks amounted to 239 man hours per hectare - by 1987 it had been reduced to $126 \mathrm{~h} /$ ha (Agricultural Economics Research Institute of Finland publications Vol 4, 142). At the beginning of the 1960's work involving a horse or a tractor accounted for $40 \mathrm{~h} / \mathrm{ha}$ and $16 \mathrm{~h} / \mathrm{ha}$ respectively. In 1987 only 3 percent of the farms participating in the study had horses and horse assisted work amounted to 55 hours per annum per farm. The corresponding figure for work involving tractors was 21 hours/ha and for combine harvesters 42 hours/farm.

Tractors were widely used in agricultural work already in the early 1960 's. Thanks to larger and more powerful machines the use of tractors, especially in working the fields, has not increased significantly in terms of hours/ha, although tractors are now used to transport even the smallest loads, and many new tasks involve tractor-operated machines (OKSANEn 1971).

\section{Research on Agricultural Mechanization}

The mechanization of work has played a significant part in the Finnish agricultural 
technology research during the last quarter century. This general term refers to research on and the development of new working methods and the machines, equipment, structures etc. to suit these methods. The research objectives may have included achieving a reduction in human labour utilization and expenditure, improving the quality and accuracy of agricultural work and making it less strenuous, promoting work safety and the attractiveness of the work, energy conservation and environmental protection. The three-way relationship between Man, Biology and Technology should be born in mind when developing agricultural working methods. A purely technical solution seldom works and its concomitant biological damage may be very hard to remedy.

In the 1950's the mechanization of agriculture concentrated on converting the work in the field and the transportation work that formerly employed horses to utilize tractoroperated equipment. Thanks to their larger size and the inclusion of hydraulic systems and power take-off tractors became more useful and versatile already in the 1960's. In the 1980 's electronics are rendering tractors ever more versatile and precise.

As a new subject, research in agricultural technology receives relatively little public funding. The more significant research centres include the State Agricultural Engineering Research Centre VAKOLA (formerly Agricultural Machinery Research Institute), which has had to operate mainly as a testing facility for agricultural machinery, the Agricultural Engineering Department of Helsinki University (originally the Institute of Agricultural Techniques), which is only 20 years old and has limited research resources, and the state subsidized Work Efficiency Institute, which has frequently had to rely on project funding. Certain foundations, agricultural machinery manufacturers and the trade have sponsored research on agricultural technology, mainly of an applied nature. Relatively little basic research has been undertaken.

\section{Soil cultivation, fertilization and sowing}

Combined drilling may be considered the most significant, expressly Finnish research result. The work began as far back as 1958 with a field experiment designed by Professor Salonen, and continued through the 1960's and in some respects beyond that decade (KARA and RÄISÄNEN 1974). It resulted in a method whereby a combined drill deposits the fertilizer in the soil between every two seed rows at about 1'' (20-30 mm) below the sowing depth. Compared to broadcast fertilizing this method increases crop yields by 14 per cent (range $0-40 \%$ ) with the same amount of fertilizer. Nitrogen absorption improves and the crop ripens more evenly. The use of irrigation sprinklers complements this fertilizer placement method: crop yields are up by 60 to 65 per cent compared to a test field with broadcast fertilizing and without sprinkler irrigation.

The method has been studied in several countries, but the results have not been as good further south. Huhtapalo and HeinoNEN (1968) achieved an 8 per cent increase in crop yield in Sweden. In Finland combined drilling made a breakthrough early in the 1970 's. By 1974 this method was employed in 70 per cent of all spring sowing. The Finnish agricultural machinery industry has delivered considerable numbers of combined drills even to countries outside Scandinavia, and these machines are now being manufactured in other countries as well.

Combined drilling is also beneficial in terms of manpower utilization. Further developments of the method have led to the adoption of loose weight supplies or large packaging units of fertilizer, hopper cars and low profile combined drills with large containers. The work is faster and less strenuous than before, but requires ever more expensive machinery and eguipment, rendering this method uneconomical on small farms. Research has contributed to the fine tuning of the method and the detailed designs of farming appliances. 
Work using the combined drill should be preceded by at least some tilling with other equipment. Practically inclined farmers and machinery manufacturers have built a harrow or a rotary tiller to the front end of the combined drill. That way they can work the fields tilled in the preceding autumn in one single operation. Winter grain can be sown straight in stubble fields. Research has also contributed to further developments of the method and its design details, e.g. tines and drill coulters. In terms of labour utilization the method is advantageous, but crop yields and their quality have varied. Notable improvements have not always been achieved.

Combined drilling is an ecologically beneficial and economical method, as the fertilizer will not go to waste or run into ditches and water systems. Liquid manure should also be injected in order to achieve the same level of accuracy. Soil compaction is a serious problem, especially in the spring when liquid manure should, according to research findings, be distributed in the fields by a trailer. A trailer for liquid manure is too slow to use during the busy period in the spring. It is more suitable for fertilizing grass.

\section{Plant protection}

In recent years technological research has focussed on more accurate crop spraying techniques and the reduction of control substances (herbicides and pesticides). These objectives can be reached with up-to-date and reconditioned sprayers. Research institutes and equipment manufacturers have participated in this developmental work. Pesticides in particular pose an ergonomical risk, and it is necessary for the sprayer to wear a good mask and other protective gear, jointly developed by research and industry.

\section{Harvesting grass}

The use of silage has increased at the expense of dried hay. The research and develop- mental work focussing on methods, machinery and appliances, silos and silage processing equipment has produced fairly effective methods that apply the findings of biological research on plants, fertilization and manuring, preservatives and animal nutrition.

\section{Harvesting grain crops}

The increased cost of energy from 1974 to 1985 accelerated the research (and its funding), first on crop drying and later on combine harvesting, as carried out at the State Research Institute of Engineering in Agriculture and Forestry and the Work Efficiency Institute. It was discovered that combine harvesters are normally driven too slowly, resulting in low output and high threshing losses. Our Finnish summer wheat, at least, needs to be threshed by gentler methods than those presently employed. The energy consumption of hot-air drying has been reduced by nearly a quarter with the aid of more accurate monitoring equipment and by insulating hotair driers. Simple solar collectors increase the efficiency of cold-air driers. Foreign research results have not been of much value, as they have generally been obtained under more favourable harvesting conditions.

\section{Harvesting potatoes and other root crops}

Agricultural technology research has also contributed to the mechanized harvesting of root crops. The mechanized harvesting and handling of potatoes is prone to inflict damage and reduce the quality of the crop. The best of machines cannot produce good results if used carelessly or ignoring the operating instructions. This fact has proved significant enough for the Agricultural Development Fund and the Finnish National Fund for Research and Development to have sponsored research that produced, among other results, a manual. 
Potato cultivation has its own new research centre where the entire work cycle of potato growing and its alternative solutions are being studied. Its objective is to produce a better quality potato with less work and expense. The Sugar Beet Research Centre has been operating meritoriously for a long time, developing the biology and technology specific to this field, supporting its mechanization in the process.

\section{Horticulture}

Technological research combined with biological research have in many ways promoted growing crops under glass as well as outdoor. The HERKO project of the Work Efficiency Institute, assisted by the Finnish National Fund for Research and Development and the berry processing industry, is a good example of interdisciplinary research. An English currant picking machine was modified and the resulting Finnish version is now being manufactured for local use and export. It applies a labour-saving method, reducing picking costs to about a half of those for manual picking. Damage to the berry shrubs has been brought under control by means of plant pathological research and developments in cultivating methods, disease control and machinery.

The high cost of energy in the late 1970's accelerated research on greenhouses and warehouses worldwide. Considerable savings in heat energy could be effected by relatively simple measures. Studies on energy conservation in gardening, agriculture and other fields led to a drop in the demand for oil and a reduction in its price in early 1986. An increase in the use of alternative energy sources, in Finland peat, wood chips and to some extent straw, had a similar effect. Agricultural technology has contributed considerably to studies of energy utilization in terms of the work cycle and equipment involved.

\section{Animal husbandry and buildings}

In animal husbandry mechanization has lagged behind that of field crop cultivation. Overproduction and restrictions on production have hampered the free development of this line of farming. Agricultural building research has been in a state of flux throughout the 1970's and to some extent still in the 1980's. Research on materials and structures has been carried out largely with an industrial bias.

Larger and interdisciplinary research projects include NAPERO (cowshed renovation ergonomics), partially sponsored by the Finnish Academy and implemented at university level, and MAKA (the feasibility of milk production) backed by VALIO (a large dairy and food processing company) and carried out by several universities and other institutes. Both adopted a technical/economical approach, supplemented by medicine and veterinary medicine in the case of NAPERO, and animal and plant biology in the case of MAKA. Both projects have produced results beneficial to dairy barn designing and construction techniques, human and animal health, production techniques and economy.

In animal husbandry feeds are a major in pig farming the foremost - item of expenditure. Exact feeding in terms of milk production or growth is crucial for economical production. Automatic equipment has been developed for this purpose. Electronics may be applied widely in spheres other than animal husbandry and building as well.

\section{Occupational Health and Work Safety}

Much of the research on agricultural engineering has focussed on occupational health, work safety and attractiveness. The tractor cabin is no longer the shaking, vibrating, noisy and dusty den that it was at the end of the 1960's. White fingers (Raynaud's phenomenon) no longer afflict chain saw operators. The presence of mould dust while handling 
hay, straw or wood chips is acknowledged and protective countermeasures are adopted, toxic gases are avoided, dangerous parts of machines and appliances are kept encased or covered sensibly, etc.

\section{Technology to repair damage}

The ergonomical disadvantages of mechanized working methods are fairly well known and many have been eliminated. Operating a machine often calls for monitoring several parts or functions simultaneously, in addition to steering, as in the case of the combine harvester. Man's ability to effectively divide his attention without deviating from the optimal speed is limited. Electronic and other automatic devices can monitor various functions and make adjustments, leaving the operator free to steer the machine.

Soil compaction in the fields is a severe disadvantage. Growth is hampered, subsurface drainage malfunctions etc. Technical solutions alone cannot restore the soil structure. It is

\section{References}

Ajankohtaista maatalousekonomiaa. Kirjanpitotilojen tuloksia tiliv. 1987. 1989. Maatal. tal. tutk.lait. julk. 142: 1-46.

Huhtapalo, Ȧ. \& Heinonen, R. 1968. Inledande försök med gödselradmylling kombinerad med sådd 1964 -66. Lantbr.högsk. rapp. från jordbearbetningsavd. 4: $1-36$.

Indicators of the Finnish economy. 1989. EVA. 42 p. Helsinki.

KARA, O. \& RĀISĀNen, L. 1974. Sijoituslannoituksen ke- necessary to resort to other strategies, including plant selection and crop rotation, leaving fields to lie as green fallow, etc. Environmental disadvantages can generally be remedied by technological solutions, often coupled with biological measures.

Buildings that do not blend in the rural landscape may be considered another kind of a disadvantage. The worst mistakes can be prevented by applying the findings of research on the rural cultural landscape and its protection.

\section{Summary}

Research on agricultural technology has been mainly applied, emphasizing the product development of agricultural machinery. Interdisciplinary projects or composite research, where problems have been solved through biology, engineering and economy, not forgetting ergonomics, energy conservation and environmental protection, have produced the most significant results.

\footnotetext{
hityksestä ja tutkimustoiminnasta Suomessa. J. Scient. Agric. Soc. Finland 46, 3: 175-184.

Oksanen, E.H. 1971. Peltoviljelykoneiden kãytöstaa, kestoiăistä ja poistamissyistă. Maatal.tiet. aikak.kirja 43: 203-212.

Suomela, S. 1958. Tuottavuuden kehityksestä Suomen maataloudessa. Maatal. tal. tutk.lait. julk. 1: 1-128.

Tutk. S. maatal. kannatt. XLIX, tiliv. 1960-61. 1962. Maatal. tal. tutk.lait. julk. 4: 1-69.
} 